\title{
“Zhivaia Starina” (“Living Tradition”): An Academic Journal
}

\author{
Dmitry Nikolaev \\ Centre for Typological and Semiotic Folklore Studies \\ Russian State University for the Humanities \\ Moscow, Russia
}

\begin{abstract}
Zhivaia Starina (Living Tradition) is an academic journal published by the State Republican Center of Russian Folklore [http://www.centrfolk.ru].(1) Its primary focus is Russian folklore and traditional culture, but it also publishes articles on folklore and ethnography of other (mostly Slavic) peoples, as well as comparative and theoretical papers. All the articles are in Russian. The magazine is distributed through subscription in Russia and other countries. Each issue is divided into sections, of which some are regular features (field materials, book and conference reviews, lists of new publications on folklore and ethnography) and some are specific to the volume in question, reflecting its particular themes.
\end{abstract}

Volume 1 (57), 2008, is dedicated largely to theoretical issues. The first section is "Theoretical Questions" and it includes "Voice and Echo of Myth" by S. Iu. Nekliudov, this is a paper on the problem of myth as a worldview and literary category. K. Procházková's article is about the ATU 650A "Strong John" motif in Russian folktales. The author argues that this motif forms a transition from myth to classical folktale. S. Niebrzegowska-Bartmińska explores some models of the structure of oral texts using the "complex"-oriented approach found in the works of L. S. Vygotskii. The final article in section one is "Principles of cyclization in chastushkas" by E. M. Afans'eva.

The second section is "Epic Traditions." It includes an article on the principles of the ethno-geographical distribution of oral epics entitled "Another Epic Universal?" by I. I. Zemtsovsky. N. V. Drannikova and Iu. A. Novikov offer information on new recordings of byliny. K. Rangočev gives a review of the history and of the current state of the Bulgarian heroic epic ("junaški") tradition.

Problems of the ethics of fieldwork and the difficulties arising in the process of communication between fieldworker and informant, as well as general methodological issues concerned with collecting folkloristic data are dealt with in the third section. Examples are drawn from different ethnic environments. Northern Russia is covered in articles by A. B. Moroz and K. A. Balobanova. Estonians in Siberia (2) are dealt with by 
A. Korb. Spain is discussed by N. V. Voziakova. Mongolia is discussed by S. Iu. Nekliudov, who also gives a survey of the modern state of the Mongolian popular tradition. Some Mongolian field recordings, new and archival, are published in Issue 3, 2008 (see below).

Volume 2 (58), 2008, is devoted to Slavic folklore. The first section, "Days of the Week in Popular Culture," includes an overview paper by S. M. Tolstaia entitled "Days of the Week in Popular Magic."(3) There are a series of case studies with an analysis of the symbolism of the "semidionnaia nedeliushka" ("week of seven days") in Slavic wedding songs by N. V. Kurguzova. There is an article on beliefs about the particular characteristics of Tuesdays and Saturdays among Eastern Slavs by S. N. Amosova and one on the particular characteristics of Thursday in the Vladimir oblast' by V. E. Dobrovol'skaia. The two remaining articles in this section treat local holidays: "The Cycle of Local FridayHolidays in the North-East of Moscow Oblast"" by O. N. Glazunova and "'Shirokie Subboty' ['Lavish Saturdays'] in the Calendar of the Kama Region Russians" by A. V. Chernykh. Papers on aspects of popular culture are collected in the section "Slavic Patchwork" and include an article entitled "The Motif of Invitation to a Wedding in Slavic Spells" by T. A. Agapkina, an article by K. V. P'iankova on the food (or just empty plates) served to mark the end of a feast, and a survey of the functions of the Eucharist (prosphora) in Bulgarian popular culture by I. Miškova. This section also has a survey of the celebration of the Octave of Easter in Polesie by O. V. Belova and a note on a special church bread called artos and its role in Easter services by I. R. Kilachitskaia. The last thematic section in this issue is entitled "The Interaction of Ethnic Traditions." In this section A. A. Plotnikova treats the popular traditions of Slavic enclaves in Romania and Austria (small groups of Russian Old Believers and Croats respectively).(4) D. Iu. Doronin writes about the supposed traces of the ancient paganism of the Mari people in the contemporary popular cult centered on the chapel of Basil of Caesarea in Odnoshur, Nizhnii Novgorod oblast'. Buriat legends in the folklore repertoire of Russians living in the Baikal Region are the subject of E. L. Tikhonova's contribution. Finally there are interview excerpts published by V. V. Vinogradova which present the recollections of villagers in western and north-western Russia about their relationships with Gypsies prior to the 1956 decree which prohibited nomadic itinerancy.

Volume 3 (59), 2008, has two main subject sections: "Popular Art" and "Folklore of Peoples from Around the World: Mongolian Peoples." The first section contains several articles on the techniques of Russian 
popular art and on problems of collecting and preserving such art. It features "Icons Painted by the Peasants of Karelia" by V. P. Ershov which includes a number of reproductions from the author's private collection. "Icons from Berezaika," a report on contemporary icons painted by a non-professional couple from Tver oblast', is contributed by A. G. Kuleshov. "Embroidery, Birchbark, and Wood: The Family Craft and its Meaning" is the title of an article written by M. D. Alekseevskii. T. I. Ignat'eva and I. R. Kilachitskaia write on traditional gold, silver, and pearl embroidery on Russian church attire. V. G. Smolitskii contributes a survey of the first collections of popular art assembled by regional museums in the second half of the nineteenth century.

Mongolian materials include an analysis of new field recordings made in central and northern Mongolia during the recent expeditions of the Center for the Typology and Semiotics of Folklore at the Russian State University for the Humanities. This section includes a paper by A. V. Kozmin on the role of the constellation of Ursa Major in contemporary Mongolian tradition. There is a report on supposedly recent legends about evil sorcerers [haraalči $]$ by A. S. Arkhipova and a survey of contemporary Mongolian demonological creatures by A. A. Soloviova. There are also archival materials and new translations such as that of the tales about čutgur demons taken from the recordings made by Ts. Damdinsuren. These are translated, and prefaced by A. D. Tsendina. Short Mongolian myths and legends from different sources were prepared and published by L. G. Skorodumova, Ia. D. Leman, and E. O. Chernyshova. Also in this section are the following papers: "Fieldwork Observations on the Religious/Mythological Traditions of the Buriats and Kalmyks" by A. I. Kuznetsova and "Sexual/Erotic Motifs in the Shamanic Incantations of Buriats" by L. S. Dampilova.

Volume 4 (60), 2008, is again mostly Slavic in content. The first three articles are grouped under the title "Oral Text, Literary Text". They include an analysis by J. Bartmiński of the Polish/Ukrainian popular game "Zelman" as a paratext. There is a study on the sources of the Eastern Slavic dream interpretation tradition by A. V. Chernetsov and a survey of versions of the popular ballad "Woman of Samaria" in Old Believer and Molokan traditions by S. E. Nikitina. The second section, called "Mythological Elements in Slavic Tradition," includes papers on diverse subjects. Among them is an article on the symbolism of the vine by L. Radenkovič and a piece about the motif of "a witch who rides a man" by L. N. Vinogradova. There are reports on witch beliefs among the Old Believers of Romania by A. A. Plotnikova and about the 
circumstances for entering the other world as reflected in the retellings of dreams and visions by E. V. Safronov. M. A. Andronina writes about the spatial characteristics of calendar memorial rites. The third section, "Ritual and Magical Practices", begins with a report on the function of the wreath in the wedding rites of Smolensk oblast' by M. A. Engovatova. It is followed by a cartographical analysis of the terminology used for the last sheaf (most commonly called baroda, "the beard") in Belarus by N. P. Antropov. S. Niebrzegowska-Bartmińska presents a survey of modern survivals of belief in the magical power of the word as they are attested in advertisements and political campaigns in Poland. O. A. Pashina contributes a paper about the non-official and nonorthodox religious practices of Russian villagers during the Soviet period. She describes devout women "saints" who organized churches in their homes and replaced priests who were prohibited from celebrating the Divine Liturgy. The last three articles form the section "Food in Traditional Culture." A paper by E. L. Berezovich and K. V. P'iankova treats the characteristics Russians traditionally ascribe to Lenten/weak soups and weak tea. These are treated as deviating from the strongflavored norm. A. V. Gura gives a survey of the uses of wedding porridge among the Slavic peoples, and G. I. Kabakova analyses the popular notion of feeding one's "dusha" (mind/soul) which is envisaged in popular anthropology as an internal bodily organ.

\section{NOTES}

1 Zhivaia Starina was first published in Russia between 18901917. It was then edited by V. I. Lamanskii. The publication of the journal was recommenced in 1994, with a different structure but with the same periodicity (four times a year) and volume (72 pp. per issue). The first editor-in-chief of the new Zhivaia Starina was N. I. Tolstoi; after his death in 1996, S. Iu. Nekliudov assumed editorship of the journal.

2 See the English version of this paper: Korb A., On Factors Affecting Folkloristic Fieldwork: On the Example of Estonians in Siberia, Folklore, Vol. 27, October 2004, 101-132. Available online at [http://www.folklore.ee/folklore].

3 See the review of her book Polesskii Narodnyi Kalendar' (Popular Calendar of Polesie) in Issue 1, 2008, and a jubilee overview of her scientific activities in Issue 4, 2008.

4 On Romanian Old Believers' demonological views see the paper by the same author in Issue 4, 2008. See below. 